Pak. j. sci. ind. res. Ser. B: biol. sci. 2016 59(1) 12-19

\title{
Functional Properties and Amino acid Profile of Spirulina platensis Protein Isolates
}

\author{
Shahid Bashir ${ }^{a *}$, Mian Kamran Sharif ${ }^{a}$, Masood Sadiq Butt ${ }^{a}$ and Muhammad Shahid \\ ${ }^{a}$ Faculty of Food Nutrition and Home Sciences, National Institute of Food Science and Technology, \\ University of Agriculture, Faisalabad, Pakistan \\ ${ }^{b}$ Departmant of Biochemistry, University of Agriculture, Faisalabad, Pakistan
}

(received July 14, 2015; revised September 21, 2015; accepted September 28, 2015)

\begin{abstract}
Protein malnutrition and food insecurity represent serious obstructions to sustainable development, poverty reduction and food quality throughout the world. The present study has been designed to evaluate the Spirulina platensis (SP) as a protein alternative source for the utilization in food products. A protein isolate was prepared from $S$. platensis powder through extraction with $0.1 \mathrm{~N} \mathrm{NaOH}$, precipitation at $\mathrm{pH} 3$, neutralization of the dispersed precipitate to $\mathrm{pH}$ 6.8-7.0, and subsequent freeze drying. The $S$. platensis isolate amino acids compositions revealed that the total essential amino acids contribution was comparatively higher in SPI ( $31.16 \pm 1.43 \mathrm{~g} / 100 \mathrm{~g})$ as compared with SP $(27.75 \pm 1.21 \mathrm{~g} / 100 \mathrm{~g})$. Moreover, oil and water absorption capacities, foaming and emulsifying properties, surface hydrophobicity and nitrogen solubility index were found better functional properties under laboratory conditions except emulsion properties. Conclusively, SP and its isolates might be used in various food products to curtail protein energy malnutrition.
\end{abstract}

Keywords: Spirulina platensis, amino acid, protein isolates, functional properties

\section{Introduction}

Malnutrition exists in those regions where overall food supply is inadequate due to poor economy; less access to dietary information; political unrest conditions and instability has interrupted food supplies. The tremendous increase in global population and production of insufficient protein has directed to search alternate sources of protein. The greater part of the world, especially developing countries use cereals as the staple foods that are generally deficient in lysine and threonine. Protein quality of the cereals can be improved by algal supplementation as these are good source of essential amino acids (Spolaore et al., 2006; Pimentel and Pimentel, 2003).

Spirulina (Spirulina platensis) has attained promising position among protein alternative sources due to its amino acids, fatty acids, phytonutrients and vitamin A contents. Both, Spirulina platensis and Spirulina maxima are commonly used as foods supplement. Spirulina is one of the most prehistoric life forms on earth and has been used as food by humans for centuries (Vigani et al., 2015; Habib et al., 2008). Marine protein hydrolysates can deliver nutritional benefits and play a vital role as functional ingredients for food industries along with potential use in health issues and as functional ingredients for food processing (Vijaykrishnaraj and Prabhasankar, 2015). Microalgae can be used to enhance

*Author for correspondence; E-mail: shahidft@yahoo.com the nutritional value of foods due to their abundance in compounds with beneficial attributes (Benelhadj et al., 2016).

Spirulina contains about $65-70 \%$ protein (dry weight) that is higher than any other natural food, and considered as a good protein source for human consumption. Furthermore, spirulina protein is easily digestible whilst considered more appropriate for malnourished children (Chaiklahan et al., 2011; Li et al., 2006; Khan et al., 2005). Also spirulina has a unique blend of nutrients that no single plant source can provide. It has a high protein concentration (60-70\% on dry weight), supplying 18 amino acids, including all essential amino acids in balanced proportion (Kim and Kang, 2011; Fradique et al., 2010).

Spirulina has wide food applications ranging from juice smoothies, confectionary, food bars, baked desserts, doughnuts, muffins, pasta, salad dressing, frozen desserts, snack foods, popcorn, corn chips, crackers, breakfast cereals, soups and instant meals. Spirulina protein isolates (SPI) are currently of special interest to processors and consumers due to low fat and high protein content (Widjanarko et al., 2011; Fradique et al., 2010; Hassan et al., 2010). Besides imparting nutritional and therapeutic benefits, spirulina supplementation in the food products improves the texture and colour of the products (Fradique et al., 2010). 
Spirulina protein isolates have shown good gelling properties with fairly low minimum critical gelling concentrations. Protein concentrate had a lower water absorption capacity, higher fat absorption and emulsification capacity, similar foaming capacity than its flour. Spirulina protein isolates exhibited lower viscosities at pH 9 due to increase in protein solubility. Subsequent cooling at ambient temperatures caused a further pronounced increase in network elasticity (Devi and Venkataraman, 2006; Chronakis, 2001).

In developing countries of Asia, especially South East, the pressure on food sources is increasing day by day due to escalating population and scarcity of resources. In this context, some unconventional protein sources have been explored for improving nutritional status of population (Voltarelli et al., 2011; Simpore et al., 2006). There is dire need to explore some algae based high protein sources to formulate nutritious and economical foods. Keeping in view the above facts, present project has been designed to address protein energy malnutrition and micronutrient deficiencies in vulnerable segment of population.

\section{Materials and Methods}

Spray-dried spirulina (S. platensis) strain Pacifica was purchased from Cyanotech Corporation, Hawaii, USA. The reagents (analytical and HPLC grade) were purchased from Merck (Merck KGaA, Darmstadt, Germany) and Sigma-Aldrich (Sigma-Aldrich, Tokyo, Japan). The current study was carried out at Institute of Food Science, College of Agriculture and Life Sciences, Cornell University, NY, USA.

Preparation of spirulina protein isolates. Extraction. The spirulina protein isolates were extracted by dissolution of spirulina under reductive conditions in $2 \mathrm{M}$ $\mathrm{NaOH}$ for maximum solubility. The soluble protein was separated by acidic precipitation $(2 \mathrm{M} \mathrm{HCl})$ and freezedried powder was stored at $5{ }^{\circ} \mathrm{C}$ for further analysis (Gerde et al., 2013; Chronakis, 2001). The nitrogen content was determined by using AACC Method No. 46-10 (AACC, 2000).

Protein yield. Protein yield was calculated using isolate recovery, protein content of isolates and spirulina (Wang et al., 1999).

$$
\text { Yield }(\%)=\frac{\begin{array}{c}
\text { Weight of isolate }(\mathrm{g}) \times \text { protein } \\
\text { content of isolate }(\%)
\end{array}}{\begin{array}{c}
\text { Weight of sample }(100 \mathrm{~g}) \times \\
\text { protein content of sample }(\%)
\end{array}} \times 100
$$

Functional properties. For the measurement of bulk density, spirulina protein isolates were filled in $10 \mathrm{~mL}$ graduated cylinder, and gently tapped several times until there was no further attenuation of the sample level. Oil absorption capacity was measured by mixing $0.5 \mathrm{~g}$ of spirulina isolate sample in $6 \mathrm{~mL}$ of corn oil in centrifuge tube followed by stirring to dissolve the sample in oil. After $30 \mathrm{~min}$, the tube was centrifuged at $3000 \times \mathrm{g}$ for $25 \mathrm{~min}$. The separated oil was removed by the pipette and the tubes were inverted for $25 \mathrm{~min}$ to remove the oil before reweighing. Water absorption was determined by mixing $3 \mathrm{~g}$ of sample in $25 \mathrm{~mL}$ of distilled water. The solution was stirred followed by centrifugation for $25 \mathrm{~min}$ at $3000 \times \mathrm{g}$. The resultant supernatant was decanted, excess moisture was removed and reweighed. Sample $(1 \mathrm{~g})$ was dispersed in $50 \mathrm{~mL}$ of distilled water, in a capped test tube, by shaking vigorously for $5 \mathrm{~min}$ followed by immediate pouring into a $250 \mathrm{~mL}$ graduated cylinder. The volume of the foam formed was then recorded as the foam capacity $(\mathrm{mL} / 100 \mathrm{~mL})$. A final observation was made after 60 min for recording the foam stability. Emulsifying properties were determined following the procedure described by Yasumatsu et al. (1972). Sample (0.5 g) of spirulina protein isolates was suspended in $3 \mathrm{~mL}$ of distilled water contained in a graduated tube followed by the addition of oil $(3 \mathrm{~mL})$. The contents were then shaken vigorously for $5 \mathrm{~min}$ and the resulting emulsion was centrifuged at $2000 \times \mathrm{g}$ for $30 \mathrm{~min}$. The volume of the emulsified layer divided by that of the whole slurry multiplied by 100 was taken as the emulsifying activity $(\mathrm{mL} / 100 \mathrm{~mL})$. To determine the emulsion stability, the homogenised mixture of spirulina isolates, water and oil was heated at $80^{\circ} \mathrm{C}$ for $30 \mathrm{~min}$ before centrifugation at $2000 \times \mathrm{g}$ for $30 \mathrm{~min}$. The emulsifying stability was then calculated as the volume of the emulsifying layer divided by that of the heated slurry multiplied by 100 , reported as $\mathrm{mL} / 100 \mathrm{~mL}$. While, surface hydrophobicity of spirulina protein isolates was determined by hydrophobicity florescence probe (1-anilino-8-naphthalene sulphonate ANS) and cis-parinaric acid (CPA) probes with some modifications by using SLM 8000 Spectrofluorimeter (Slm Aminco Instruments, Inc. Rochester, NY, USA), with adjusted wavelengths of 390 and $470 \mathrm{~nm}$ for excitation and emission, respectively (Alizadeh-Pasdar and Li-Chan, 2000; Kalapathy et al., 1997). Nitrogen solubility index was determined following the method described by Shand et al. (2007); Betschart (1974) and AACC Method No.46-23 (AACC, 2000) and . The least gelation concentration was determined by the methods of Sathe and Salunkhe (1981) and Siddiq et al. (2010). 
Amino acid profile. Amino acid profiles of spirulina were determined at the Agricultural Experiment Station Chemical Laboratories, University of Missouri (Columbia, MO), by using AOAC Method No.982.30E (AOAC, 2011) by injecting known volume of the supernatant of the prepared samples using high speed amino acid analyzer (L-8500 A, Hitachi, Tokyo, Japan) by modifying the method described by Adeyeye and Afolabi (2004).

Statistical analysis. All the experiments were run in triplicate. The collected data were statistically analyzed by t-test using Statistical Package (Statistix 8.1) and expressed as mean $\pm \mathrm{SD}$.

\section{Results and Discussion}

Protein contents and yield of spirulina proteins isolates. Mean values for the protein content and yield of spirulina proteins isolates (Table 1) revealed $74.01 \pm 1.53 \%$ protein content and $52.60 \pm 3.46 \%$ yield. Isolation of proteins from microalgae further enhances the commercial value by increasing food applications (Schwenzfeier et al., 2011).The Spirulina platensis strain Pacifica protein isolates were extracted by dissolution of the algae under reductive conditions in $\mathrm{NaOH}$ exhibited greater solubility followed by acidic precipitation and freeze-drying (Devi and Venkataraman, 2006). The spirulina extracted protein isolate revealed protein content of 67.9 and $67.8 \%$ using method of AOAC (1995), respectively. Minor variations in protein content of fractions $(67.9 \%)$ were noticed for the sample before fractionation (Chronakis et al., 2000). Spirulina protein is generally well balanced, reflecting its potential as human food and as a source of natural products. Spirulina is slightly acidic and carries a negative charge at neutral $\mathrm{pH}$. However, the presence of salts reduces the solubility of spirulina protein, contrasting to other proteins like soybean meal (Chronakis, 2001).

Functional properties of spirulina protein isolates. The functional properties of proteins mainly depend upon interaction with three important components of food systems including oil, water and gas. Protein plays a major role as surface active agent; functionality depends simultaneously on efficiency to absorb into the wateroil or oil-water interfaces, film forming ability, and ability to prevent coalescence. Interaction of protein with water is main factor to establish the solubility behaviour along with viscosity and gelling, though interaction with oil and gas indicates the emulsifying and foaming properties.
Processing brings certain structural modifications in proteins altering their functionality. Exposure of proteins to variable temperatures may either dissociate the oligomers into subunits or formation of new units due to coagulation. Sometimes, these irreversible changes may lead to loss of protein quality as well as hydration, viscosity, biological activity and solubility.

Bulk density, absorption capacities and surface hydrophobicity. Bulk density specifies packaging behaviour of manufactured products depends on collective effect of some unified factors like particle size, forces and strength of contact points. The maximum bulk density (Table 2) was observed in spirulina protein isolates $\left(0.64 \pm 0.07 \mathrm{~g} / \mathrm{cm}^{3}\right)$ followed by spirulina sample $\left(0.58 \pm 0.04 \mathrm{~g} / \mathrm{cm}^{3}\right)$. The lower bulk density of powdered spirulina may have been due to textural porosity leading to lower bulk density whereas in spirulina protein isolates sheerness of particle size facilitated the proper reconciling of isolates thus improving the bulk density value.

Protein has both hydrophobic and hydrophilic properties which influence the interaction with oil and water in various foods. Water and oil binding properties are an evaluation of physicochemical interaction of proteins with other components in food. Spatial rearrangement in protein structure during heat processing may alter its

Table 1. Protein content and yield of spirulina proteins isolates

\begin{tabular}{ll}
\hline Parameter & Quantity (\%) \\
\hline Protein content & $74.01 \pm 1.53$ \\
Protein yield & $52.60 \pm 3.46$ \\
\hline \hline
\end{tabular}

Values are means $\pm S D,(n=3)$.

Table 2. Functional properties of spirulina and spirulina protein isolates (SPI)

\begin{tabular}{lll}
\hline \hline Properties & Spirulina & SPI \\
\hline Bulk density $\left(\mathrm{g} / \mathrm{cm}^{3}\right)$ & $0.58 \pm 0.04$ & $0.64 \pm 0.07$ \\
Water absorption $(\mathrm{mL} / \mathrm{g})$ & $2.14 \pm 0.18$ & $2.96 \pm 0.17$ \\
Oil absorption $(\mathrm{mL} / \mathrm{g})$ & $1.85 \pm 0.21$ & $0.59 \pm 0.16$ \\
Surface hydrophobicity & $25.34 \pm 0.18$ & $17.13 \pm 0.21$ \\
Foaming capacity (mL) & $10.74 \pm 0.27$ & $12.53 \pm 0.16$ \\
Foaming stability (min) & $19.26 \pm 3.87$ & $32.40 \pm 4.53$ \\
Emulsion activity (\%) & $56.32 \pm 1.54$ & $51.54 \pm 2.12$ \\
Emulsion stability (\%) & $71.51 \pm 1.20$ & $65.20 \pm 2.17$ \\
\hline \hline
\end{tabular}

Values are means \pm SD; SPI $=$ spirulina protein isolates; $(n=3)$. 
absorption properties. Higher water absorption capacity of spirulina protein isolates $(2.96 \pm 0.17 \mathrm{~mL} / \mathrm{g})$ may have been due to presence of more polar amino acids at primary cites of protein-water interface (Table 2). Likewise, lower water absorption capacity was noticed in spirulina $(2.14 \pm 0.18 \mathrm{~mL} / \mathrm{g})$. On the contrary, spirulina protein isolates showed lower oil absorption capacity $(0.59 \pm 0.16 \mathrm{~mL} / \mathrm{g})$ than spirulina $(1.85 \pm 0.21 \mathrm{~mL} / \mathrm{g})$.

Surface hydrophobicity is an index of protein interaction capacity with other molecules in polar aqueous environment and is strongly correlated with emulsion activity. It is very important factor in determining the emulsifying properties; lower values cannot assist the interaction between proteins and oils. Protein functionality is greatly affected by the presence of hydrophobic patches on the surface of proteins that are available to interact with food system. Means for surface hydrophobicity (Table 2) showed higher surface hydrophobicity $(25.34 \pm 0.18)$ for spirulina while spirulina protein isolates had lower values for hydrophobicity (17.13 \pm 0.21$)$. Nirmala et al. (2006) have reported water absorption (2.92 g/g) and oil absorption $(0.56 \mathrm{~g} / \mathrm{g})$ capacities of Spirulina platensis. In another study, water and oil absorption capacities of spirulina flour $(2.2 \mathrm{~g} / \mathrm{g}$ and $1.9 \mathrm{~g} / \mathrm{g}$, respectively) were comparable to soybean meal $(2.30 \mathrm{~g} / \mathrm{g}$ and $1.20 \mathrm{~g} / \mathrm{g}$, correspondingly). Protein isolates have lower water absorption capacity and higher oil absorption capacity than its flour samples (Devi and Venkataraman, 2006).

Foaming and emulsion properties of spirulina and spirulina protein isolates. Foaming properties illustrates whipping ability of protein concentrates. Protein's property to form stable foams is vital for diverse food applications. Foam is a two-phase system consisting of air cells separated by a thin continuous liquid layer, lamellar phase. The results regarding foaming and emulsion properties are presented in Table 2. Spirulina protein isolates showed the maximum foaming capacity $(12.53 \pm 0.16 \mathrm{~mL})$ and stability $(32.40 \pm 4.53 \mathrm{~min})$, compared with foaming capacity and stability of spirulina (10.74 $\pm 0.27 \mathrm{~mL}$ and $19.26 \pm 3.87 \mathrm{~min}$, respectively). Foam obtained from spirulina protein isolates appeared denser and stable due to more interaction at air-water interface. The high values of foaming capacity and stability indicate highly hydrated foams as in case of spirulina protein isolates, while decrease in both parameters was observed in case of spirulina. The foaming stability of spirulina (18\%) and spirulina protein concentrate $(27 \%)$ was poor when compared to soybean meal (55\%) (Devi and Venkataraman, 2006). Foaming capacity depends on diffusion of protein at air-water interface by unfolding its structure while foaming stability is dependent on formation of thick cohesive layer around the air bubbles (Damodaran, 1997).

The results pertaining to emulsion activity and stability revealed that spirulina and spirulina protein isolates exhibited $56.32 \pm 1.54$ and $51.54 \pm 2.12 \%$ emulsion activity, respectively, while emulsion stability for spirulina and spirulina protein isolates was $71.51 \pm 1.20 \%$ and $65.20 \pm 2.17 \%$, respectively. This was may be due to more surface area and fine particles. Emulsifying capacity and stability of microalgae (Chlorella vulgaris) proteins are comparable or superior to the commercial ingredients i.e. sodium caseinate (Ursu et al., 2014). Spirulina has similar emulsion and foaming capacity to that of soybean meal. Guil-Guerrero et al. (2004) evaluated functional properties of three microalgae species along with soy bean. The emulsifying capacity of three alga $(50 \mathrm{~g} / \mathrm{g}$ of oil at $\mathrm{pH} 4$ and $20 \mathrm{~g} / \mathrm{g}$ of oil at $\mathrm{pH} 12)$ were higher than soybean $(50 \mathrm{~g} / \mathrm{g}$ of oil at $\mathrm{pH} 4$ and $90 \mathrm{~g} / \mathrm{g}$ at $\mathrm{pH} 12$ of oil).

Least gelation concentration of spirulina and spirulina protein isolates. Least gelation concentration is a qualitative parameter to work out the concentration at which the protein isolates form a gel. Spirulina protein isolates exhibit good gelling properties (Table 3) with least gelation concentration (LGC) of $18 \%$ compared with spirulina (14\%). Microalgae can be an alternative and novel source of natural ingredient for development of novel food products. Batista et al. (2013), findings

Table 3. Least gelation concentration spirulina and spirulina protein isolates

\begin{tabular}{lll}
\hline \hline Concentration (\%) & Spirulina & SPI \\
\hline 2 & $(-)$ & $(-)$ \\
4 & $(-)$ & $(-)$ \\
6 & $(-)$ & $(-)$ \\
8 & $(-)$ & $(-)$ \\
10 & $( \pm)$ & $(-)$ \\
12 & $( \pm)$ & $( \pm)$ \\
14 & $(+)$ & $( \pm)$ \\
16 & $(+)$ & $( \pm)$ \\
18 & $(+)$ & $(+)$ \\
20 & $(+)$ & $(+)$ \\
LGC & 14 & 18 \\
\hline \hline
\end{tabular}

Gelation levels: $(-)=$ liquefied; $( \pm)=$ gluey; $(+)=$ gel; LGC $=$ least gelation concentration; $(n=3)$; SPI $=$ spirulina protein isolates. 
elucidates that, by elevated temperature (upto $90{ }^{\circ} \mathrm{C}$, $5 \mathrm{~min})$ and the effect of time $\left(5-30 \mathrm{~min}\right.$, at $\left.90{ }^{\circ} \mathrm{C}\right)$ was less noticeable to form more structured gels. Spirulina protein isolates have relatively good gelling properties, with a critical gelling concentration of $1.5 \% \mathrm{w} / \mathrm{w}$ in aqueous solution. Hydrophobic interactions were also found to stabilize the structure of spirulina protein gels. Hydrogen bonds are suggested to add the network rigidity. Furthermore, intermolecular disulphide bonds have found to play a trivial role for the network structure of spirulina protein gels (Chronakis et al., 2001).

Nitrogen solubility index of spirulina and spirulina protein isolates. Solubility depends on the physicochemical characteristics of the protein molecules and affects its functional properties like emulsification, foaming and gelling properties. The nitrogen solubility is expressed as the percentage of the total nitrogen that remains in the supernatant of spirulina protein extract that was obtained after acid $(0.1 \mathrm{~N} \mathrm{HCl})$ and alkali $(0.1 \mathrm{~N}$ $\mathrm{NaOH}$ ) treatment. It is a good index considered while designing any potential applications for flour proteins. Minimum nitrogen solubility (4.55-4.68\%) was observed at $\mathrm{pH} 4.0$ might be due to isoelectric region. A marked boost was observed above this point till $\mathrm{pH} 8.0$ (55.04$80.41 \%$ ), followed by a slight raise up to $\mathrm{pH} 12.0$ where, protein isolates illustrates a solubility index ranging from $77.67 \%$ to $90.54 \%$ (Fig. 1). Overall, spirulina revealed poor solubility as compared to its isolates. Lower solubility profile of spirulina was due to the strong aggregation during drying and heating conditions.

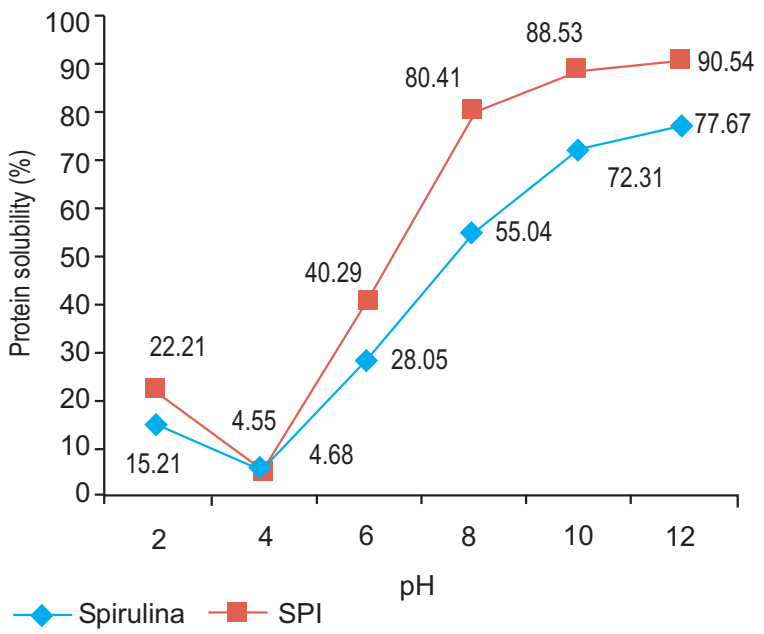

Fig. 1. Nitrogen solubility index of spirulina and spirulina protein isolates $(n=3)$.
There is positive correlation within nitrogen insolubility and protein aggregation index. Protein that shows denaturalization aggregation properties has lower gelation, foaming capacities and emulsification (GuilGuerrero et al., 2004).

The $\mathrm{pH}$ has significant impact on nitrogen solubility. In a study, lower nitrogen solubility was noticed at pH 4 in defatted microalgae biomass followed by rapid increase $(75 \%)$ at $\mathrm{pH} 12$. It might be due to cell wall inhibition in the solubility of the protein at basic pH (Guil-Guerrero et al., 2004). Micro-alga biomass consumption without any treatment to break the cell wall e.g., sonication, might affect the maximum body utilization of the algal protein (Oshodi, 1992). Defatted micro-alga biomass can be used in the formulation of acid foods such as milk analog products, and proteinrich carbonated beverages (Kinsella, 1976).

Amino acids profile of spirulina and spirulina protein isolates. Quality of protein depends normally on its essential amino acid content. Results regarding amino acid profile of spirulina and spirulina protein isolates are given in Table 4 and 5. The results for essential amino acids in spirulina and spirulina protein isolates exhibited; leucine in large proportion $(6.81 \pm 0.19 \mathrm{~g} /$ $100 \mathrm{~g})$ followed by valine $(4.72 \pm 0.13 \mathrm{~g} / 100 \mathrm{~g})$ whilst the lowest value $(0.98 \pm 0.03)$ was noted for tryptophan in spirulina protein isolates. Likewise, leucine $(6.17 \pm 0.23$ $\mathrm{g} / 100 \mathrm{~g})$ and valine $(4.21 \pm 0.10 \mathrm{~g} / 100 \mathrm{~g})$ were major essential amino acids in spirulina. The total essential amino acid contribution was comparatively high in spirulina protein isolates $(31.16 \pm 1.43 \mathrm{~g} / 100 \mathrm{~g})$ than that of spirulina $(27.75 \pm 1.21 \mathrm{~g} / 100 \mathrm{~g})$.

Table 4. Essential amino acids profile of spirulina and spirulina protein isolates

\begin{tabular}{lll}
\hline \hline Amino acids & Spirulina $(\mathrm{g} / 100 \mathrm{~g})$ & SPI $(\mathrm{g} / 100 \mathrm{~g})$ \\
\hline Phenylalanine & $3.33 \pm 0.12$ & $3.75 \pm 0.14$ \\
Methionine & $1.71 \pm 0.11$ & $1.82 \pm 0.05$ \\
Threonine & $3.31 \pm 0.07$ & $3.73 \pm 0.10$ \\
Valine & $4.21 \pm 0.10$ & $4.72 \pm 0.13$ \\
Isoleucine & $3.64 \pm 0.20$ & $4.24 \pm 0.12$ \\
Leucine & $6.17 \pm 0.23$ & $6.81 \pm 0.19$ \\
Lysine & $3.40 \pm 0.02$ & $3.85 \pm 0.11$ \\
Histidine & $1.13 \pm 0.04$ & $1.26 \pm 0.06$ \\
Tryptophan & $0.85 \pm 0.02$ & $0.98 \pm 0.03$ \\
TEAA & $27.75 \pm 1.21$ & $31.16 \pm 1.43$ \\
\hline
\end{tabular}

Values are means $\pm \mathrm{SD}$; TEAA $=$ total essential amino acids; $\mathrm{SPI}=$ spirulina protein isolates; $(\mathrm{n}=3)$. 
Table 5. Non-essential amino acids of spirulina and spirulina protein isolates

\begin{tabular}{lll}
\hline \hline Amino acids & Spirulina $(\mathrm{g} / 100 \mathrm{~g})$ & $\mathrm{SPI}(\mathrm{g} / 100 \mathrm{~g})$ \\
\hline Alanine & $5.02 \pm 0.07$ & $5.65 \pm 0.16$ \\
Arginine & $4.47 \pm 0.05$ & $5.04 \pm 0.14$ \\
Aspartic acid & $6.31 \pm 0.16$ & $7.14 \pm 0.20$ \\
Glutamic acid & $8.47 \pm 0.19$ & $9.57 \pm 0.27$ \\
Glycine & $3.43 \pm 0.10$ & $3.89 \pm 0.11$ \\
Proline & $2.53 \pm 0.04$ & $2.91 \pm 0.08$ \\
Cysteine & $0.64 \pm 0.03$ & $0.72 \pm 0.02$ \\
Tyrosine & $3.07 \pm 0.05$ & $3.41 \pm 0.09$ \\
\hline \hline
\end{tabular}

Values are means $\pm \mathrm{SD}$; SPI $=$ spirulina protein isolates; $(n=3)$.

The results for non-essential amino acids in spirulina and spirulina protein isolates indicated glutamic acid as major amino acid $(9.57 \pm 0.27 \mathrm{~g} / 100 \mathrm{~g})$ followed by aspartic acid $(7.14 \pm 0.20 \mathrm{~g} / 100 \mathrm{~g})$ whereas, the lowest content $(20.72 \pm 0.02 \mathrm{~g} / 100 \mathrm{~g})$ was noticed for cysteine in spirulina protein isolates. Similarly, glutamic acid $(8.47 \pm 0.19 \mathrm{~g} / 100 \mathrm{~g})$ and aspartic acid $(6.31 \pm 0.16 \mathrm{~g} /$ $100 \mathrm{~g}$ ) were substantial amounts. It is obvious from the results that both spirulina and spirulina protein isolates are good source of leucine, valine, isoleucine, lysine, glutamic acid, aspartic acid, alanine and arginine. The levels of methionine and alanine are comparatively high in spirulina with most commonly used plant protein source i.e. soybean.

The nutritional quality of a protein is determined mostly by the proportion, content and availability of its amino acids (Becker, 2007; WHO, 2007). The protein contents in algae contain all essential amino acids and some species can be compared with soy and egg protein (Galland-Irmouli et al., 1999). In addition, the right combination of plant proteins can ensure the supply of satisfactory amounts of essential amino acids for human health (Day, 2013). The natural dried spirulina of Cuban origin was analyzed for amino acid contents through reverse-phase HPLC. It was observed that, valine and leucine contents were in high proportion (6.1 and 6.0 $\mathrm{g} / 100 \mathrm{~g}$ ) on dry weight basis. Furthermore, amino acid analysis showed the highest value $(101 \mathrm{mg} / \mathrm{g})$ for glutamic acid (Campanella et al., 1999). Most of the algae contain lysine and sulphur containing amino acids i.e. methionine and cysteine (Simpore et al., 2006). In addition, high concentrations of arginine, aspartic acid and glutamic acid are found in many seaweed species (Dawczynski et al., 2007; Fleurence, 1999;). The levels and pattern of amino acids in spirulina are similar as reported by FAO. Cereals are generally low in limiting amino acids like lysine and tryptophan whereas, these amino acids are present in high concentration in spirulina which can be an excellent choice for supplementation in cereals and cereals based diets (WHO, 2007).

\section{Conclusion}

Quality of protein depends on its essential amino acid content. It is obvious from the results that both spirulina and spirulina protein isolates are good source of leucine, valine, isoleucine, lysine, glutamic acid, aspartic acid, alanine and arginine. The levels of methionine and alanine are comparatively high in spirulina with most commonly used plant protein source i.e. soybean. Histidine was found to be the first limiting amino acid in both spirulina and spirulina protein isolates. The functional properties of proteins mainly depend upon interaction with three important components of food systems including oil, water and gas. Spirulina protein isolates revealed higher bulk density, water absorption capacity, foaming capacity and foaming stability and good gelling properties.

\section{Acknowledgement}

The author is highly thankful to Higher Education Commission of Pakistan for providing financial support in both programmes i.e. under indigenous scholarship programme in University of Agriculture Faisalabad and International Research Support Initiative Programme for Cornell University, USA.

\section{References}

AACC, 2000. Approved Methods of the American Association of Cereal Chemists, vol. 1-2, pp. 1-3, $10^{\text {th }}$ edition, The American Association of Cereal Chemists. Inc., St. Paul, Minnesota, USA.

Adeyeye, E., Afolabi, E.O. 2004. Amino acid composition of three different types of land snails consumed in Nigeria. Food Chemistry, 85: 535-539.

Alizadeh-Pasdar, N., Li-Chan, E.C.Y. 2000. Comparison of protein surface hydrophobicity measured at various $\mathrm{pH}$ values using three different fluorescent probes. Journal of Agricultural and Food Chemistry, 48: 328-334.

AOAC, 2011. The Official Methods of Analysis of AOAC International, $18^{\text {th }}$ edition. The Association of Official Analytical Chemists, Arlington, USA.

AOAC, 1995. The Official Methods of Analysis of $A O A C$, Method $969.03,192$ pp., 16 $6^{\text {th }}$ edition. The 
Association of Official Analytical Chemists, Arlington, USA.

Batista, A.P., Gouveia, L., Bandarra, N.M., Franco, J.M., Raymundo, A. 2013. Comparison of microalgal biomass profiles as novel functional ingredient for food products. Algal Research, 2: 164-173.

Becker, E.W. 2007. Micro-algae as a source of protein. Biotechnology Advances, 25: 207-210.

Benelhadj, S., Gharsallaoui, A., Degraeve, P., Attia, H., Ghorbel, D. 2016. Effect of $\mathrm{pH}$ on the functional properties of Arthrospira (Spirulina) platensis protein isolate. Food Chemistry, 194: 1056-1063.

Betschart, A.A. 1974. Nitrogen solubility of alfalfa protein concentrate as influenced by various factors. Journal of Food Science, 39: 1110-1115.

Campanella, L., Crescentini, G., Avino, P. 1999. Chemical composition and nutritional evaluation of some natural and commercial food products based on spirulina. Analusis, 27: 533-540.

Chaiklahan, R., Chirasuwan, N., Loha, V., Tia, S., Bunnag, B. 2011. Separation and purification of phycocyanin from Spirulina sp. using a membrane process. Bioresource Technology, 102: 7159-7164.

Chronakis, I.S. 2001. Gelation of edible blue-green algae protein isolate (Spirulina platensis strain pacifica): thermal transitions, rheological properties, and molecular forces involved. Journal of Agricultural and Food Chemistry, 49: 888-898.

Chronakis, I.S., Galatanu, A.N., Nylander, T., Lindman, B. 2000. The behaviour of protein preparations from blue-green algae (Spirulina platensis strain Pacifica) at the air/water interface. Colloids and Surfaces A: Physicochemical and Engineering Aspects, 173: 181-192.

Damodaran, S. 1997. Food Proteins and their Applications, pp. 1-25, Institut National de la Recherche Agronomique Centre de Recherches de Tours Nouzilly, France, Marcel Dekker Inc., New York, USA.

Dawczynski, C., Schubert, R., Jahreis, G. 2007. Amino acids, fatty acids, and dietary fiber in edible seaweed products. Food Chemistry, 103: 891-899.

Day, L. 2013. Proteins from land plants: potential resources for human nutrition and food security. Trends in Food Science and Technology, 32: 2542.

Devi, M.A., Venkataraman, L.V. 2006. Functional properties of protein products of mass cultivated blue-green alga Spirulina platensis. Journal of Food Science, 49: 24-27.
Fleurence, J. 1999. Seaweed proteins: Biochemical, nutritional aspects and potential uses. Trends in Food Science and Technology, 10: 25-28.

Fradique, M., Batista, A.P., Nunes, M.C., Gouveia, L., Bandarra, N.M., Raymundoa, A. 2010. Incorporation of Chlorella vulgaris and Spirulina maxima biomass in pasta products-Part-1: preparation and evaluation. Journal of the Science of Food and Agriculture, 90: 1656-1664.

Galland-Irmouli, A.V., Fleurence, J., Lamghari, R., Luçon, M., Rouxel, C., Barbaroux, O., Guéant, J.L. 1999. Nutritional value of proteins from edible seaweed Palmaria palmata (dulse). The Journal of Nutritional Biochemistry, 10: 353-359.

Gerde, J.A., Wang, T., Yao, L., Jung, S., Johnson, L.A., Lamsal, B. 2013. Optimizing protein isolation from defatted and non-defatted Nannochloropsis microalgae biomass. Algal Research, 2: 145-153.

Guil-Guerrero, J.L., Navarro-Juarez, R., Lopez-Martýnez, J.C., Campra-Madrid, P., Rebolloso-Fuentes, M.M. 2004. Functional properties of the biomass of three microalgal species. Journal of Food Engineering, 65: 511-517.

Habib, M.A.B., Parvin, M., Huntington, T.C., Hasan, M.R. 2008. A Review on Culture, Production and Use of Spirulina as Food for Humans and Feeds for Domestic Animals and Fish, pp.1-33. FAO Fisheries and Aquaculture Circular Rome, Italy.

Hassan, H.M.M., Afify, A.S., Basyiony, A.E., Ahmed, G.T. 2010. Nutritional and functional properties of defatted wheat protein isolates. Australian Journal of Basic and Applied Sciences, 4: 348-358.

Kalapathy, U., Hettiarachchy, N.S., Rhee, K.C. 1997. Effect of drying methods on molecular properties and functionalities of disulfide bond-cleaved soy proteins. Journal of the American Oil Chemists Society, 74: 195-199.

Kaur, M., Singh, N. 2007. Characterization of protein isolates from different Indian chickpea (Cicer arietinum) cultivars. Food Chemistry, 102: 366374.

Khan, Z., Bhadouria, P., Bisen, P.S. 2005. Nutritional and therapeutic potential of spirulina. Current Pharmaceutical Biotechnology, 6: 373-379.

Kim, S.K., Kang, K.H. 2011. Medicinal effects of peptides from marine microalgae. Advances in Food and Nutrition Research, 64: 313-323.

Kinsella, J.E. 1976. Functional properties of proteins in food: a survey. Critical Reviews in Food Science and Nutrition, 7: 219-280. 
Li, Z.Y., Guo, S.Y., Li, L. 2006. Study on the process, thermodynamical isotherm and mechanism of $\mathrm{Cr}$ (III) uptake by Spirulina platensis. Journal of Food Engineering, 75: 129-136.

Nirmala, C., Prakash, V., Venkataraman, L.V. 2006. Physico-chemical and functional properties of proteins from spray dried algae (Spirulina platensis). Food Nahrung, 36: 569-577.

Oshodi, A.A. 1992. Proximate composition, nutritionally valuable minerals and functional properties of Adenocarpus breviflorus Benth seed flour and protein concentrate. Food Chemistry, 45: 79-83.

Pimentel, D., Pimentel, M. 2003. Sustainability of meatbased and plant-based diets and the environment. The American Journal of Clinical Nutrition, 78: 660-663.

Sathe, S.K., Salunkhe, D.K. 1981. Functional properties of the Great Northern Bean (Phaseolus vulgaris L.) Proteins: emulsion, foaming, viscosity and gelation properties. Journal of Food Science, 46: 71-74.

Schwenzfeier, A., Wierenga, P.A., Gruppen, H. 2011. Isolation and characterization of soluble protein from the green microalgae Tetraselmis sp. Bioresource Technology, 102: 9121-9127.

Shand, P.J., Ya, H., Pietrasik, Z., Wanasundara, P.K.J.P.D. 2007. Physicochemical and textural properties of heat-induced pea protein isolate gels. Food Chemistry, 102: 1119-1130.

Siddiq, M., Ravi, R., Harte, J.B., Dolan, K.D. 2010. Physical and functional characteristics of selected dry bean (Phaseolus vulgaris L.) flours. LWT-Food Science and Technology, 43: 232-237.

Simpore, J., Kabore1, F., Zongo, F., Dansou, D., Bere, A., Pignatelli, S., Biondi, D.M., Ruberto, G., Musumeci, S. 2006. Nutrition rehabilitation of undernourished children utilizing spiruline and misola. Nutrition Journal, 5: 1-7.

Spolaore, P., Joannis-Cassan, C., Duran, E., Isambert, A. 2006. Commercial applications of microalgae.
Journal of Bioscience and Bioengineering, 101: 87-96.

Ursu, A.V., Marcati, A., Sayd, T., Sante-Lhoutellier, V., Djelveh, G., Michaud, P. 2014. Extraction, fractionation and functional properties of proteins from the microalgae Chlorella vulgaris. Bioresource Technology, 157: 134-139.

Vigani, M., Parisi, C., Rodríguez-Cerezo, E., Barbosa, M.J., Sijtsma, L., Ploeg, M., Enzing, C. 2015. Food and feed products from micro-algae: Market opportunities and challenges for the EU. Trends in Food Science and Technology, 42: 81-92.

Vijaykrishnaraj, M., Prabhasankar, P. 2015. Marine protein hydrolysates: their present and future perspectives in food chemistry-a review. RSC Advances, 5: 34864-34877.

Voltarelli, F.A., Araujo, B.M., Moura, L.P., Garcia, A., Silva, C.M.S., Junior, R.C.V., Melo, F.C.L., Mello, M.A.R. 2011. Nutrition recovery with spirulina diet improves body growth and muscle protein of protein-restricted rats. International Journal of Nutrition and Metabolism, 3: 22-30.

Wang, M., Hettiarachchy, N.S., Qi, M., Burks, W., Siebenmorgen, T. 1999. Preparation and functional properties of rice bran protein isolate. Journal of Agricultural and Food Chemistry, 47: 411-416.

WHO, 2007. Protein and Amino Acid Requirements in Human Nutrition. Report of a Joint FAO/WHO/ UNU Expert Consultation, WHO Technical Report Series 935. World Health Organization, Geneva, Switzerland.

Widjanarko, S.B., Nugroho, A., Estiasih, T. 2011. Functional interaction components of protein isolates and glucomannan in food bars by FTIR and SEM studies. African Journal of Food Science, 5: 12-21.

Yasumatsu, K., Sawada, K., Moritaka, S., Misaki, M., Toda, J., Wada, T., Ishii, K. 1972. Whipping and emulsifying properties of soybean products. Agriculture and Biological Chemistry, 36: 719-727. 